\title{
Legal Protection of Violence Against Women in Semarang City, Indonesia
}

\author{
Ratna Herawati ${ }^{1}$, Sekar Anggun Gading Pinilih ${ }^{2}$, Ani Purwanti ${ }^{3}$ \\ \{ratna_h27@yahoo.com ${ }^{1}$, sekar_anggun@live.undip.ac.id ${ }^{2}$,ani_purwanti81@yahoo.com $\left.{ }^{3}\right\}$ \\ Faculty of Law, Diponegoro University, Indonesia ${ }^{123}$
}

\begin{abstract}
The number of violence against women in Semarang City every year continues to increase, even become areas with the highest cases of violence in the Central Java. Therefore, Semarang City needs to do efforts to protect women from violence. This study aims to examine the efforts of Semarang City Government to protect the women from violence's. This research is a normative law research by laws. The data used are secondary data, which consist of primary law and secondary law materials. The result shows Semarang City already stipulate Local Act number 5 of 2016 on the Protection of Women and Children from Violence to reduce a number of violence of women. In addition, various efforts are also made by Semarang City, such as established an Integrated Service Center that helps the Department of Women Empowerment and Child Protection of Semarang City; providing Rumah Duta Revolusi Mental (RDRM) as a shelter and legal aid victims of violence's and bullying to women and children, in coordination with other agencies, and socialization the law to the public.
\end{abstract}

Keywords: Legal Protection; Women; Violences; Semarang City

\section{Introduction}

Indonesia is a legal state as stipulated in Article 1 paragraph (3) of the 1945 Constitution of the Republic of Indonesia. The concept of a legal state that adheres to the rule of law, according to Dicey, contains three elements, namely:

1. Human rights are guaranteed by law;

2. Equality before the law;

3. Supremacy of legal rules and no arbitrariness without clear rules (Kurdie, 2005).

However, Indonesia has its own characteristics as a state based on law, with its elements, including:

1. The law comes from Pancasila

2. People's sovereignty

3. Constitutional system

4. Equal position in law and government for every citizen.

5. The power of the judiciary which is free from the influence of other powers.

6. The legislators are the president together with the DPR.

7. Use of the MPR system.(Prasetyo, 2010)

As a democratic legal country, Indonesia recognizes equality in law and government for every citizen without exception, including women and children. In addition, Indonesia is 
obliged to guarantee and recognize Human Rights as stated in Article 28 I paragraph (4) of the 1945 Constitution of the Republic of Indonesia, as the objective of the Indonesian State as contained in the Preamble of the 1945 Constitution. Violence against women is a violation of law and human rights. Violence as a violation of law today has become a factual phenomenon in people's lives. Violence against women in Indonesia is increasing.

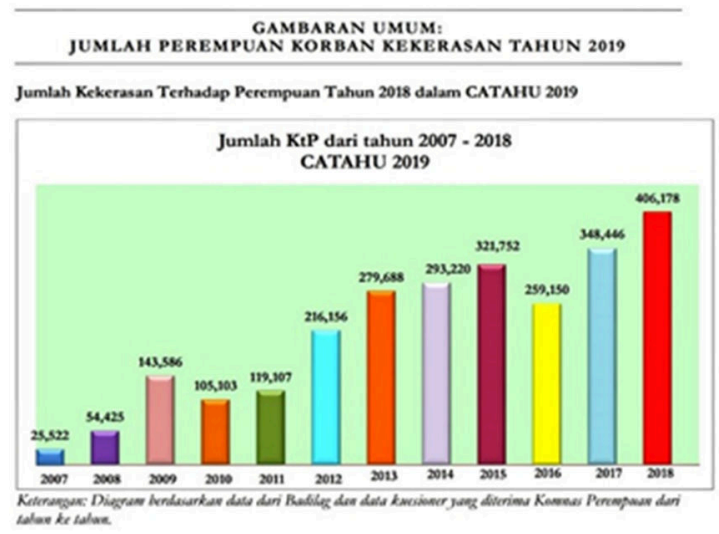

Fig1. Number of violence against women in 2007-2018

The data in the diagram above shows a very rapid increase in the number of violence against women in the country of Indonesia from 2007 to 2018. In 2009, for example, the increase occurred in the amount of more than 5 times from 2007, namely from 25.522 people increased 143.586 people. Likewise in 2016 to 2018, that is an increase of 1.5 times, namely 259.150 people and 406.178 people respectively. From 2012 to 2015 there was an almost equal increase, namely 216.156 people, 279.688 people, 293.220 people, and 321.752 people. Although there has been a decrease in the number of violence that occurred in 2009 to 2010 and 2015 to 2016. However, this did not last long because the following year there was an increase again.

Looking at the data above, legal protection for women needs to be given because violence against women is understood by the wider community, lawmakers and government officials are limited to sexual violence only. The lack of understanding of women about violence and its consequences makes women tend to surrender and accept the situation. In addition, violence is carried out in marital ties so that women do not report it to the authorities (Gultom, 2013). Violence occurs because women are considered to be in a position below men. "The extension and legitimacy of patriarchal practices in the personal-intimate domains of the aspects of public life impinge on the lives, rights and freedoms of women" (Imam, Shadab, Bano, 2015).

Indonesia has ratified an international convention with the Law Number 7 of 1984 on Ratification of the Convention on the Elimination of All Forms of Discrimination Against Women, as a consequence of the ratification of the international convention is participating countries of the convention give commitment, commit themselves to guarantee through legislation, policies, programs and temporary special measures, to realize equality and justice between men and women, and to eliminate all forms of discrimination against women (Irianto, 2006). Legal protection for women in Semarang City should get serious attention. Legal Resources Center for Gender Justice and Human Rights Semarang, noted that throughout 2016 there were 496 cases of violence against women in Central Java Province. This number is 
spread in each district and city in Central Java. The most cases occurred in Semarang City with 199 cases, followed by Kendal with 26 cases, Sragen with 17 cases, Blora with 17 cases, Magelang District and Surakarta City with 16 cases ("Kota Semarang Peringkat Pertama Kasus Kekerasan pada Perempuan di Jateng," n.d.).

In 2017, in Semarang City there were 118 cases. Looking at the number of violence against women and children which is increasing from 2014-2017, Semarang City is the highest region of violence against women in Central Java Province. This is based on the number of cases of violence against women cases which reached 236 cases in 2014, which consisted of 169 cases of violence against women (Pusat Pelayanan Terpadu SERUNI Kota Semarang, 2014). This number has increased to 278 cases in 2015 , consisting of 188 cases of violence against women and 90 cases of violence against children (Pusat Pelayanan Terpadu SERUNI Kota Semarang, 2015).

This condition, if without a serious treatment, will destroy the lives of households, communities, nations and countries. Violence against women is an estuary of signs that discrimination is still ongoing against women in the culture of life. In violent behavior, women are the most vulnerable groups as victims. Legal protection for women is not solely for the fulfillment of victims' rights, but in greater interest is an effort to stop the culture of violence.

\section{Methods}

This research is normative juridical method. The data used are secondary data, which consist of primary law and secondary law materials. In its relation to normative research, the writer uses two approaches, they are statute approach and conceptual approach. Statute approach is an approach done towards many law related to violences to women and other organic law which has relation with the object of the study. Conceptual approach is used to know the concepts of protection law. The data of this research through studying those documents are then analyzed by using content analysis method.

\section{Results and Discussion}

\subsection{Impact of Violence on Women}

Forms of violence against women such as sexual, physical, harmful traditional practices, socio-economic, and emotional psychological. Violence against women not only disrupts physical health, but also mental health problems. Women who live with violent experiences will express anxiety, fear, and reluctance to believe. Women with mental illness are overtly vulnerable and much worse. Being mentally fit all the time, such as being more likely to be exploited, violated and deprived of their rights (Kaur, 2018). Legal systems and cultural norms often treat violence against women not as a crime, but as a family problem or a normal part of life. This is in line with the opinions of Shamima Akhter and Kyoko Kusakabe:

"The divide between public and private issues is" invisible "- either literally, since it happens behind closed doors, or effectively, since legal systems and cultural norms too often treat it, but as a family matter or a normal part of life (Akhter, Kyoko Kusakabe, 2014).

The processes leading to individual's perception of gender discrimination caused perceived gender bias against women. Women with mental illness are very vulnerable and have far 
worse consequences. Serious abuse commonly results in women experiencing anxiety, depression, panic attacks, suicidal ideation, or abusing substances (Tutty, 2015).

\subsection{Overview of Cases of Violence Against Women in Semarang City}

The increase in violence against women encourages the government to find solutions by regulating it through various laws and regulations. Women will experience suffering that is very diverse, both physical, material, social, and psychological. The severity of the impact that will be felt by the victims makes the government must carry out legal protection intensively and effectively. The regulation of national law related to legal protection against women is the Law Number 23 of 2004 on the Elimination of Domestic Violence.

The Law Number 23 of 2004 on the Elimination of Domestic Violence is a law relating to other legislation that has been in effect before, including the Law Number 1 of 1946 on the Criminal Code and its amendments, Law Number 8 of 1981 on the Criminal Procedure Code, Law Number 1 of 1974 on Marriage, Law Number 7 of 1984 on Ratification of the Convention on the Elimination of All Forms of Discrimination Against Women (CEDAW). Protection in Article 1 number 4 of the Law Number 23 of 2004 is defined as all efforts aimed at providing security to victims carried out by families, advocates, social institutions, police, prosecutors, courts, or other parties both temporarily and based on court determination. Article 3 of the Law Number 23 of 2004 states that the elimination of domestic violence must be carried out based on:

1. Respect for human rights;

2. Justice and gender equality;

3. Non-discrimination; and

4. Protection of victims.

The forms of violence that are prohibited in the home in Article 5 of the Law Number 23 of 2004 are:

1. Physical violence;

2. Psychic violence;

3. Sexual violence; and

4. Domestic neglect.

Women are often the object of gender based violence in the home. The existence of this law is expected to free women in Indonesia from violence and oppression that often occur in the home. Physical, psychological, sexual violence and neglect that are often experienced by women are increasingly worrisome. The increasing number of cases requires a solution that can solve this problem fundamentally, but this problem is not an easy problem. Resolving the problem of violence against women requires support from all elements of society.

Based on data from the Women's Empowerment and Child Protection Service of Central Java Province, Semarang City had the highest rate of violence against women in Central Java Province. The types of violence against women in more detail can be seen in the following table:

Table 1. Number of Violence Against Women in Semarang City based on the Form of Violence

\begin{tabular}{|c|l|c|c|c|}
\hline No. & \multicolumn{1}{|c|}{ Form of violence } & $\mathbf{2 0 1 6}$ & $\mathbf{2 0 1 7}$ & $\mathbf{2 0 1 8}$ \\
\hline 1. & Physical violence & 91 & 107 & 138 \\
\hline
\end{tabular}




\begin{tabular}{|c|l|c|c|c|}
\hline 2. & Psychological Violence & 135 & 85 & 155 \\
\hline 3. & Sexual violence & 22 & 8 & 17 \\
\hline 4. & Exploitation & 0 & 1 & 1 \\
\hline 5. & Human trafficking & 2 & 1 & 15 \\
\hline 6. & Neglect & 62 & 45 & 67 \\
\hline 7. & Others & 1 & 6 & 8 \\
\hline
\end{tabular}

Table 2. Number of Violence Against Women in the City of Semarang based on places of the violence

\begin{tabular}{|c|l|c|c|c|}
\hline No. & \multicolumn{1}{|c|}{ The Places of Violence's } & $\mathbf{2 0 1 6}$ & $\mathbf{2 0 1 7}$ & $\mathbf{2 0 1 8}$ \\
\hline 1. & Household & 355 & 147 & 195 \\
\hline 2. & Working places & 2 & 1 & 2 \\
\hline 3. & Public facility & - & 6 & 9 \\
\hline 4. & School & - & 0 & 0 \\
\hline 5. & Others & 117 & 11 & 22 \\
\hline
\end{tabular}

Based on data from Women's Empowerment and Child Protection Service in Central Java Province, cases of violence against women in the city of Semarang in 2016 to 2018 were dominated by violence in the household in the form of psychological and physical violence. Psychological violence experienced a significant increase from 2017 to 2018, which is almost 2 times increase. This can illustrate that violence against women not only caused in physical illness, but also to psychological illness. The more ironic thing is that it happens in the home itself, both the actors are husbands, parents, children, family/relatives, or anyone who lives together in the house. Here are data on violence against women in Semarang City in 2016 and 2018 based on the characteristics of the actors:

Table 3. Number of Violence Against Women in the Semarang City based on the Actor

\begin{tabular}{|c|l|c|c|}
\hline No. & \multicolumn{1}{|c|}{ Actors } & $\mathbf{2 0 1 6}$ & $\mathbf{2 0 1 8}$ \\
\hline 1. & Husband/wife & 140 & 181 \\
\hline 2. & Parents & 43 & 36 \\
\hline 3. & Family/relatives & 10 & 11 \\
\hline
\end{tabular}




\begin{tabular}{|c|l|c|c|}
\hline 4. & Friends/boyfriends & 32 & 41 \\
\hline 5. & Neighbor & 21 & 20 \\
\hline 6. & Employer & 1 & 3 \\
\hline 7. & Teacher & 3 & 8 \\
\hline 8. & Co-workers & 0 & 1 \\
\hline 9. & Others & 23 & 56 \\
\hline
\end{tabular}

In 2017, data on violence against women based on actors in all districts/cities in Central Java Province was not recorded in the Women's Empowerment and Child Protection Service of Central Java Province.

\subsection{Efforts made by the Semarang City Government in Protecting Women from Violence's}

Women are people that are often identified with the weak who need special protection from acts of violence. Women as part of society, especially residents of Semarang City have the right to obtain legal protection from acts of violence. Thus, the population of women in the city of Semarang can be better protected, so that community security and welfare can be achieved. In terms of carrying out the mandate of the Law Number 23 of 2004 on the Elimination of Domestic Violence, Semarang City has issued Local Regulation Number 5 of 2016 on the Protection of Women and Children from Violence. The local regulation gives responsibility to the Local Government starting from the prevention of acts of violence to the handling of victims of acts of violence.

Based on the provisions of Article 8 paragraph (1) Local Regulation of Semarang City Number 5 of 2016 on the Protection of Women and Children from Violence, the obligations and responsibilities of the Semarang City Government include:

1. establish, implement policies, programs, and carry out collaborative activities in the implementation of protection of women and children from acts of violence;

2. facilitate the establishment of institutions for the protection of women and children from violence and provide support for facilities and infrastructure;

3. allocating budget for the protection of women and children from acts of violence in accordance with regional financial capacity;

4. develop and supervise the implementation of protection of women and children from acts of violence;

5. providing services to protect women and children victims of violence;

6. encourage and increase community participation;

7. appoint replacement parents as a protection measure for children who are victims of violence.

In order to carry out the responsibilities as mandated by the Local Regulation of Semarang City Number 5 of 2016 on the Protection of Women and Children from Violence, the Semarang City Government issued several programs and policies, as follows: 
Establishment of a Gender-Based Integrated Service Center for Handling Violence Against Women and Children at the city and sub-district level.

Establishment of integrated services center handling gender-based violence against women and children is a mandate of the Local Regulation of Semarang City Number 5 of 2016. Integrated services center are established at the city and sub-district level. Integrated services center at the Semarang City level are referred to as Seruni. In addition to Seruni integrated service center, Semarang City also formed a integrated services center on sub districts. The services and service mechanisms provided by Seruni integrated service center and sub district integrated service center, which refer to the Mayor of Semarang Regulation Number 10 of 2011 are Legal Consultations; Legal protection; Legal Assistance; and Legal Handling. Procedures for legal services for women and children victims of violence can be seen in the following chart:

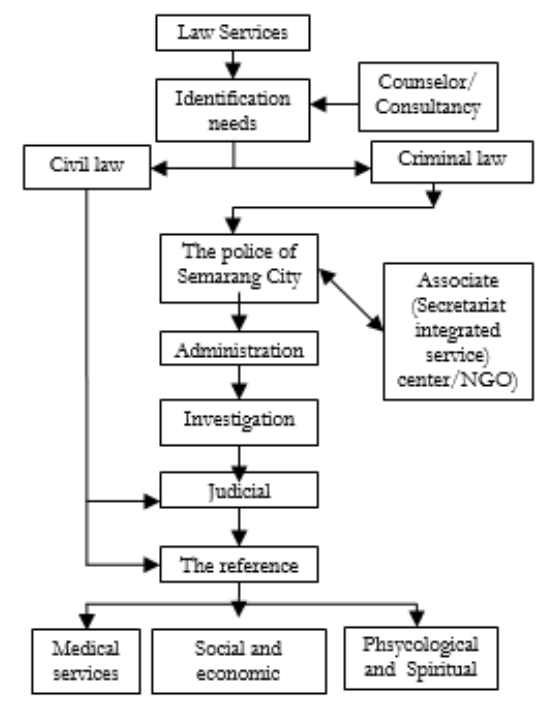

Fig 2. The Procedure of law service for women and children abused

Providing Rumah Duta Revolusi Mental (RDRM) as a shelter to protect and gives legal assistance for victims of violence and bullying to women and children.

Bullying and violence especially towards children and women are still high. The Semarang City Government made the shelter to minimize the incident. RDRM is a follow-up to Presidential Instruction Number 12 of 2016 on the National Movement for Mental Revolution. RDRM is a manifestation of programs to improve public health services, social welfare, quality of education, empowerment of women in the fields of mental health and psychosocial use of information technology systems and face to face. RDRM is the result of the collaboration of the Seruni Integrated Service Center, the Women's Empowerment and Child Protection Service, and society.

Providing services to people who take advantage of the existence of the shelter, the Semarang City Government provides supporting facilities that are comfortable and complete. The room includes a psychological counseling room, a child counseling room, a legal counseling room, an IT room, a meeting room, a kitchen and a fairly large courtyard. In addition, there are also 2 psychologist counselors with 3 auxiliary staff and 1 legal counselor with 1 assistant who is ready to serve in this RDRM. 
Programs that can be accessed by the public free of charge in RDRM, namely:

1. Restorative Justice Program

This program is a school-based restorative justice program in the field of recovery of children who are faced with law and child-friendly mediation.

2. Moral and Character Education Program

This program is a great moral education and character program for children and adolescents in Semarang City.

3. Public Mental Health Program

The mental and psychosocial health service program for the community in Semarang City.

4. Community Development Program, Action Research

Semarang City community development program to achieve better psychosocial conditions

5. Human Resource Development Program

Competency development program in career preparation for young people or great citizens.

The public can submit complaints to RDRM in two ways, namely by directly to the RDRM headquarters and getting through the website. If the community comes directly, then by filling out the guest book and consultation form first, the community will be presented with a counselor or counseling counselor. If the community really needs a psychological therapy, it will be taken to a psychologist to get further services. The second way is to visit the website. On the page, the public will be asked to fill in their identity and content as well as complaints. However, the page only seems to be for women and children, even though the mandate of the Presidential Instruction Number 12 of 2016 concerning the National Revolutionary Mental Movement is not only for women and children, but for all Indonesian people.

Basically, this shelter still have some of the weaknesses in serving victims of violences against women and children, are:

1. Security system for the occupants of the shelter is still not guaranteed because there is only one guard to save the victim.

2. Counseling services for victims is still less available.

3. Space to empowerment of victims that does not exist.

\section{Make Coordination between Institutions.}

Semarang City Government in dealing with victims of violence always coordinates with the Central Java Province, NGOs, Police, Regional Hospitals, and the Women's and Children's Services Unit. However, this coordination also experienced obstacles, such as budget problems, limited integrated service center and the lack of knowledge of the police regarding handling cases.

\section{Conduct Dissemination of the Rights of Women and Children in Legal Protection from Violence.}

Not all people know the rights of women and children in legal protection from acts of violence. The Semarang City Government made an effort to socialize laws and regulations relating to acts of violence against women and children, and to encourage the public to actively participate in reporting acts of violence against women and children. In addition, Women's Empowerment and Child services of the Semarang City serves students or communities who will conduct research that supports the elimination of violence against 
women and children. Results these studies can help them preventing and resolving cases of violence against women and children that occur in community.

\section{Conclusion and Recommendation}

Legal protection for women in Semarang City should get serious attention because the number of violence against women in Semarang City every year continues to increase, even become areas with the highest cases of violence in the Central Java. Therefore, Semarang City has issued Local Regulation Number 5 of 2016 on the Protection of Women and Children from Violence to protect the women and children from violence's. To run Local Regulation Number 5 of 2016, the Semarang City Government issued several programs and policies, are: establishment of a gender-based Integrated Service Center; providing a shelter to protect and gives legal assistance for victims of violence and bullying to women and children; make coordination between Institutions; and conduct dissemination of the rights of women and children in legal protection from violence.

That efforts have some of the weaknesses, such as: security system for the occupants of the shelter is still not guaranteed because there is only one guard to save the victim; counseling services for victims is still less available; space to empowerment of victims that does not exist; budget problems; limited integrated service center; and the lack of knowledge of the police regarding handling cases of violence against women and children. To overcome the weaknesses, the government should provide counselor for counseling services in a shelter; ensure the security system for the occupants of the shelter; provide spaces to empowerment of victims; provide more budget based on gender; and give training for the policeman to handling the cases.

\section{Acknowledment}

This research is taken from Penelitian Dasar Unggulan Perguruan Tinggi research, 1st year, with title "Kajian Akademis Perlindungan Hukum Dalam Mengurangi Angka Kekerasan Terhadap Perempuan Sebagai Upaya Peningkatan Kesehatan Mental Di Provinsi Jawa Tengah", funded by The Ministry Research, Technology, and Higher Education of Indonesia, fiscal year 2019.

\section{References}

[1] Akhter, Kyoko Kusakabe, S. (2014). Gender-based Violence among Documented Rohingya Refugees in Bangladesh. Indian Journal of Gender Studies, 21(2), 225-246. https://doi.org/10.1177/0971521514525088

[2] Gultom, M. (2013). Perlindungan Hukum terhadap Anak dan Perempuan. In Kumpulan Makalah-makalah Seminar (p. 15). Bandung: Refika Aditama.

[3] Imam, Shadab, Bano, Z. (2015). Patriarchy, Community Rights and Institutions for Education: Counterdiscourse and Negotiation for Rights. Indian Journal of Gender Studies, 22(2), 283. https://doi.org/10.1177/0971521515574608

[4] Irianto, S. (2006). Perempuan dan Hukum. Jakarta: Yayasan Obor Indonesia.

[5] Kaur, K. (2018). Implications of the Mental Healthcare Act, 2017 on the Rights of Women with Mental Illnesses in India. Journal of International Women's Studies, 19(4), 2. Retrieved from http://vc.bridgew.edu/jiws/vol19/iss4/2

[6] Kota Semarang Peringkat Pertama Kasus Kekerasan pada Perempuan di Jateng. (n.d.). Retrieved December 2, 2017, from http://jateng.tribunnews.com

[7] Kurdie, N. A. (2005). Telaah Kritis Teori Negara Hukum. Yogyakarta: Pustaka Pelajar. 
[8] Prasetyo, T. (2010). Rule of law dalam Dimensi Negara Hukum Indonesia. Refleksi Hukum, $144-145$.

[9] Pusat Pelayanan Terpadu SERUNI Kota Semarang. (2014). Laporan Tahunan Kinerja Pusat Pelayanan Terpadu SERUNI Kota Semarang dalam Penanganan Kasus Kekerasan terhadap Perempuan dan Perlindungan Anak di Kota Semarang Tahun 2014. Semarang.

[10] Pusat Pelayanan Terpadu SERUNI Kota Semarang. (2015). Laporan Tahunan Kinerja Pusat Pelayanan Terpadu SERUNI Kota Semarang dalam Penanganan Kasus Kekerasan terhadap Perempuan dan Perlindungan Anak di Kota Semarang Tahun 2015. Semarang.

[11] Tutty, L. M. (2015). Addressing the Safety and Trauma Issues of Abused Women: A CrossCanada Study of YWCA Shelters. Journal of International Women's Studies, 16(3), 101-116. Retrieved from http://vc.bridgew.edu/jiws/vol16/iss3/8 